\title{
A cross-sectional study on Bangladeshi students regarding physiological challenges of online education
}

\author{
Saimon Shahriar ${ }^{1}$ (iD), Fahima Jannat Koly ${ }^{2}$ \\ 1 Department of Pharmaceutical Chemistry, Faculty of Pharmacy, University of Dhaka, Dhaka-1000, Bangladesh \\ 2 Department of Pharmacy, Faculty of Pharmacy, University of Dhaka, Dhaka-1000, Bangladesh
}

Keywords

Bangladesh

COVID-19

Online Education

Online Survey

Physiological Challenges

Correspondence
Saimon Shahriar
Department of Pharmaceutical Chemistry
Faculty of Pharmacy
University of Dhaka
Dhaka-1000
Bangladesh
saimonshahriar19@gmail.com

\begin{abstract}
Introduction: The COVID-19 pandemic halted educational institutions all over the world which forced a shift to online classes, a new experience for Bangladeshi students which increased their screen time. Objective: This study aimed at discerning the physiological challenges accompanied by the online education system and the compatibility of Bangladeshi students considering health and socio-demographic factors. Methods: A cross-sectional pilot study was performed based upon an online survey on students $(n=590)$ during September 1st to 14th of $2020 . \quad$ Results: Interestingly, an inevitable consequence of online education was several physiological problems. It was found that $93.9 \%$ of the participants faced some kind of physiological challenges, e.g., headaches, fatigue, eye and ear problems, from online classes. The majority of the participants (57.5\%) could not concentrate for one hour or more in online classes. Conclusion: Along with transitioning towards online education, innovative teaching methods would be helpful for the students to adapt to the 'new normal'.
\end{abstract}

\section{Introduction}

Bangladesh has not been exempt from the COVID-19 catastrophe, with more than 500 thousand confirmed cases and about 8,000 deaths by the end of 2020 . Besides the loss of lives, the educational infrastructure has taken a hit as almost $90 \%$ of the world's schools (in about 107 countries) have been closed due to this pandemic (Khati \& Bhatta, 2020; Viner et al., 2020). Audrey Azoulay, DirectorGeneral of UNESCO, presented this situation as, 'Never before have we witnessed educational disruption on such a large scale' (Demuyakor, 2020). In Bangladesh, the first three known cases were confirmed on $8^{\text {th }}$ March, 2020 and the educational institutions have been shut down from 17th March. However, traditional classes were replaced with online classes and being continued in almost all levels of learning until institutions reopen (Khati \& Bhatta, 2020).

Online education systems are different in different countries. India has been providing similar learning resources in different languages; China has been using its own platforms like Ding Ding, Tencent Meeting and Tencent Class to meet its government's 'nonstop teaching and learning' requirements, whilst Nepal has been using online applications like Google Meet, Microsoft Teams and Moodle (Bao, 2020; Chen et al., 2020). Consequently, students faced a great upheaval from their usual routine classes, in shifting to this new paradigm and reported to face a number of unfamiliar stressors and challenges in online classes (Unger \& Meiran, 2020). 
Online classes offer a variety of advantages including flexibility for both teachers and students. Students can attend classes at home, and support their parents. At the same time, they can receive parental support and solace in domestic, physiological and mental affairs, not to mention in the financial matters (Cairns, 2011). One study showed that the student performance was not dependent on the method of teaching (offline or online) provided the teacher was unchanged (Stack, 2015). Many studies concluded online education to be cheaper, more convenient and more beneficial as well as many praised it for its availability of mixed courses and ease of partaking (Fedynich, 2013). This system has a precedent too- Hong Kong enacted such techniques during the SARS and swine flu occurrences in 2002 and 2008, respectively (Barbour et al., 2011). Moreover, world renowned universities like Harvard, Massachussets Institute of Technology (MIT), Oxford, Yale and Cambridge have been taking online classes for more than a decade now (Bao, 2020; Picciano, 2017).

This system, however, has some challenges too as it is significantly different from the orthodox system (GillettSwan, 2017; Robinson \& Hullinger, 2008). Online classes are inherently challenging to the financially underprivileged students as access to internet and internetcompatible devices are essential to participate in online classes (Khati \& Bhatta, 2020). Students often find it challenging to focus in such classes leading to reduced learning satisfaction and reduced grade as well as teachers who are habituated in a board-chalk setting frequently find it challenging to cope with the online accessories (Kenny, 2002; Roth et al., 2020). Moreover, as this was a forced transition towards a new paradigm, teachers and students did not have the opportunity to prepare for or train with the new resources like online lesson plans, audio-visual contents and online evaluating systems (Bao, 2020). It is best to remember that online education constitutes much more than reading PowerPoint slides to the students; and doing more than that requires stable platforms, a facility which is lacking in many countries (Demuyakor, 2020).

Before the transition towards online education, which was instructed by the Minister of Education of Bangladesh and widely recognised as an education-friendly strategy, its feasibility was greatly debated. There was, however, no significant research done on the suitability of online or distance learning in Bangladesh despite Bangladesh Open University (BOU) having been providing such classes through radio and television media for a long time. A study found that about $82.5 \%$ students and half of the teachers favoured those classes (Islam \& Islam, 2008).
Students' willingness to attend online classes, their ability to manage the technological resources required for such classes (internet availability, suitable device, etc.), the authority's ability to provide the teachers necessary resources and the teachers' inclination towards teaching online- were all explored in previous studies (Al-Amin et al., 2021; Islam et al., 2020). However, the potential physiological challenges posed by these classes and how to minimise them were overlooked.

Online classes are associated with increased screen time which has already been increasing for years (Cillero \& Jago, 2010; Duch et al., 2013; Ferrari et al., 2019; Nikkelen et al., 2014). It has been linked with various physiological problems like obesity, insomnia and cardiovascular disorders as well as mental health problems like attention deficiency, behavioural and emotional problems (Chaput et al., 2017; Levine \& Waite, 2000; Özmert et al., 2002; Page et al., 2010; Poitras et al., 2017; The Lancet Child \& Adolescent Health, 2018). Studies have suggested that screen time should be treated as a risk factor for attention deficit hyperactivity disorder (ADHD) (Tamana et al., 2019). It has been reported that children over the age of five should not be allowed to have more than two hours of screen time per day (Tremblay et al., 2016, 2017), which was seconded by the American Academy of Paediatrics (Chang et al., 2018). Researchers have suggested a link between ear and hearing problems and the headphone use, which is a frequently utilised tool in online classes (Kim et al., 2009; Kumar et al., 2009; Peng et al., 2007; Widén et al., 2017). Similarly, headaches, eye problems, neck and back problems, frustration and internet addiction have been associated with increased screen time (Lissak, 2018; Montagni et al., 2016).

In this situation, the authors hypothesised that attending regular online classes caused a number of physiological challenges in students' lives. This study aimed to determine such physiological challenges faced by Bangladeshi students who had been attending regular online classes and to what extent these problems had been affecting the students. It also attempted to determine the relationship of these challenges with various socio-demographic factors.

\section{Methods}

\section{Study Design}

This study was a cross-sectional pilot study based on an online survey conducted using the Google Forms platform. It was performed during the first two weeks of September 2020. The survey link was shared via social media. The 


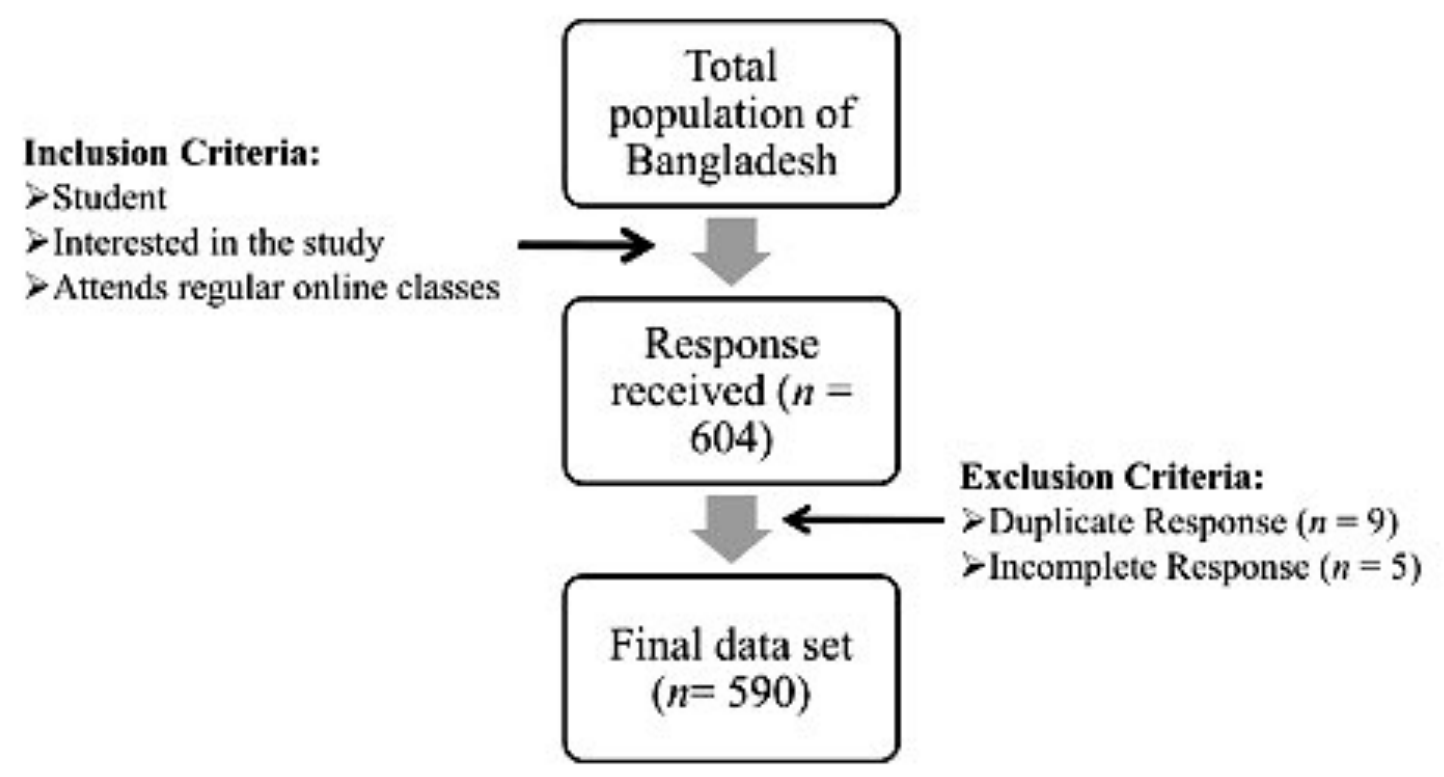

Figure 1: Data collection chart

survey propagation method was designed to get better response from the target population which was online class-attending Bangladeshi students.

\section{Participants}

A total of 604 responses were received and after applying the exclusion criteria, there were 590 valid responses. The process is displayed in Figure 1.

\section{Questionnaire}

The questionnaire was made in English as the target population were students. It consisted of both close- and open-ended questions and was structured in a way to find out participants' physiological challenges, sociodemographic factors and related information. The questions asked in the questionnaire are displayed in Table I.

\section{Ethical Issues}

A synopsis of the description and the purpose of the study along with confidentiality and anonymity declaration were given to the participants before the beginning of the survey. Participants did not have to provide their names or any sort of contact information and could choose not to participate at any point of the survey. The study was in compliance with the Declaration of Helsinki. The survey did not require the approval by the ethics committee due to the anonymous nature of the survey and the
Table I: Questions asked in the questionnaire

\begin{tabular}{|c|c|c|}
\hline Sl. No.* & Questions & Options \\
\hline 1 & What is your name? & Open-ended \\
\hline 2 & Where do you attend online classes from? & Village, City \\
\hline 3 & What is your age? & Open-ended \\
\hline 4 & You are a ___ student? & $\begin{array}{l}\text { School, College, } \\
\text { University }\end{array}$ \\
\hline 5 & You are a ___ ? & $\begin{array}{l}\text { Male, Female, } \\
\text { Prefer not to say }\end{array}$ \\
\hline 6 & What device do you use for online classes? & $\begin{array}{l}\text { Smartphone, } \\
\text { Computer/ } \\
\text { Laptop, Tab }\end{array}$ \\
\hline 7 & What do you use to hear online classes? & $\begin{array}{l}\text { Loudspeaker, } \\
\text { Headphone, Both }\end{array}$ \\
\hline 8 & $\begin{array}{l}\text { What health problems do you face from } \\
\text { attending online classes? }\end{array}$ & Open-ended \\
\hline 9 & $\begin{array}{l}\text { Did you consult a physician for these } \\
\text { problems? }\end{array}$ & Yes, No \\
\hline 10 & $\begin{array}{l}\text { What medications do you take to relieve } \\
\text { online class related health problems? }\end{array}$ & Open-ended \\
\hline 11 & $\begin{array}{l}\text { For how many hours in a day do the classes } \\
\text { continue? }\end{array}$ & Open-ended \\
\hline 12 & $\begin{array}{l}\text { How many days a week do you have online } \\
\text { classes? }\end{array}$ & Open-ended \\
\hline 13 & $\begin{array}{l}\text { How long can you concentrate on an online } \\
\text { class? }\end{array}$ & Open-ended \\
\hline 14 & In your opinion, which is more effective? & $\begin{array}{l}\text { Online classes, } \\
\text { Traditional classes, } \\
\text { Both equally } \\
\text { effective }\end{array}$ \\
\hline 15 & $\begin{array}{l}\text { What software do you use to participate in } \\
\text { online classes? }\end{array}$ & Open-ended \\
\hline 16 & Do you enjoy online classes? & Yes, No, Maybe \\
\hline 17 & $\begin{array}{l}\text { In your opinion, what can be done to } \\
\text { reduce the phy-siological problems you are } \\
\text { facing because of online classes? }\end{array}$ & Open-ended \\
\hline
\end{tabular}


impossibility of tracking sensitive personal data (Górnicka et al., 2020).

\section{Statistical Analysis}

All the collected information was analysed quantitatively and was expressed as numbers ( $\mathrm{n}$ ) and percentages. The chi-square test was used to analyse associations among the physiological challenges faced and the relevant factors. For all analyses, $p<0.05$ was considered significant. All analyses were performed using Microsoft Office Excel 2013 and IBM SPSS Statistics 20 software.

\section{Results and Discussion}

\section{Participants' Information}

A total of 590 valid responses were analysed. The breakdown of the participants' information according to

\begin{tabular}{lll}
\hline & Parameters & n (\%) \\
Sex & Female & $320(54.2 \%)$ \\
& Male & $270(45.7 \%)$ \\
Residence level & City & $446(75.6 \%)$ \\
& Village & $144(24.4 \%)$ \\
& $<11$ & $8(1.4 \%)$ \\
Age (years) & $11-15$ & $50(8.5 \%)$ \\
& $16-20$ & $219(37.1 \%)$ \\
& $21-25$ & $302(51.2 \%)$ \\
& $>25$ & $11(1.9 \%)$ \\
Current education level & High School & $9(1.5 \%)$ \\
& College & $85(14.4 \%)$ \\
& University & $421(71.4 \%)$ \\
\hline
\end{tabular}

different categories is shown in Table II.

Table II: Demographic information of the participants

\section{Physiological Challenges}

The participants were asked whether they were facing any physiological problems or challenges due to attending the online classes and if yes, what those were. The response is showed in Figure 2. 93.9\% of the participants stated that they were having at least one problem from attending these classes. The most frequently described problems were headaches, frustration, fatigue, backpain/neck pain, eye problems and internet addiction. Headaches may cause absenteeism and attention loss during classes which ultimately negates the productivity of the students (Basdav et al., 2016; Deleu et al., 2001; Menon \& Kinnera, 2013). The reason behind the fatigue might be physical (e.g., from sitting for a long time in chairs), mental (e.g., from extended periods of classes) or emotional (e.g., from the stress and anxiety caused by this pandemic) and this fatigue might hamper the learning ability of students by lowering concentration, reducing memory and diminishing cognitive skills. Ultimately, it might result in mistaken class work, forgotten assignments and homework, misunderstanding or no understanding of the topics discussed and decreased academic competence (Hafezi et al., 2010). Besides, eye problems along with headaches and fatigue, were reported to constitute computer-vision syndrome which was detrimental to ocular health and learning ability of the students (Chang et al., 2018). On the whole, all the challenges described by the participants eventually diminish the purpose of the online classes.

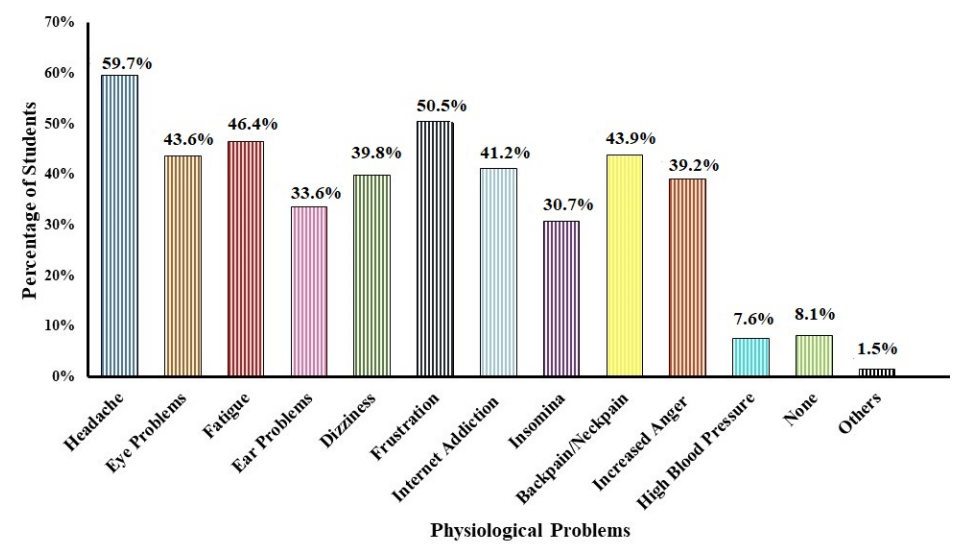

Figure 2: Physiological challenges faced by the participants

\section{Effect of the Weekly Class Load}

The authors attempted to uncover if there was a relationship between weekly class load and these problems. Information was collected from a wide variety of students and so, their weekly class loads were different. Most of the students had 11-20 or 21-30 hours of class load in a week. It was also found that the class load increased in a statistically significant manner with the increase of ages and education levels ( $p$ value 0.004 and 0.016 , respectively). University students and college students were found to bear the heaviest weekly class loads. The findings are shown in Figure 3. 

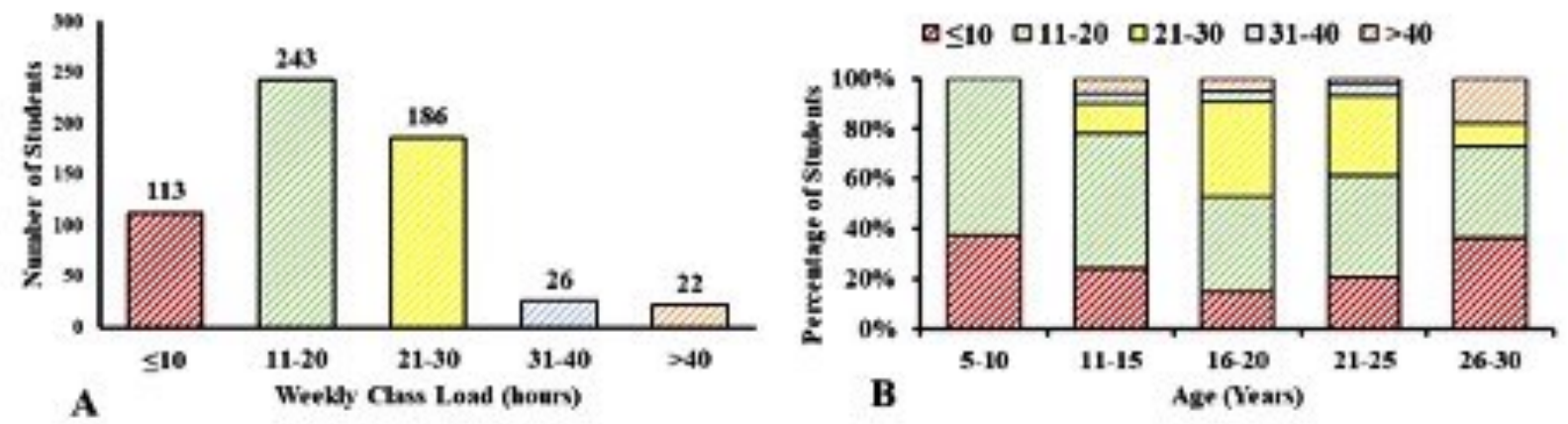

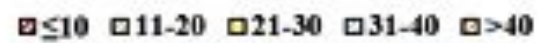

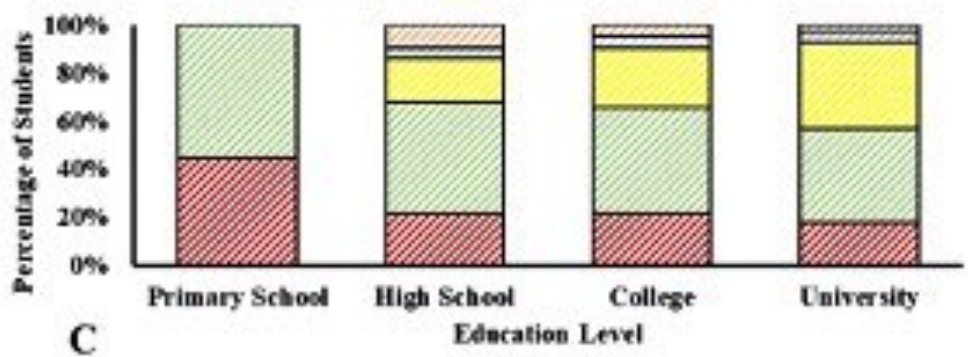

Figure 3: A. Weekly class load of the students; B. its breakdown according to ages; C. its breakdown according to education levels

It was evident in a statistically significant manner that, as a whole, heavier weekly class load was directly associated with the incitement of those physiological problems mentioned by the participants $(p=0.028)$. Increased screen time was a by-product of the increased weekly class load and this might be the reason for these problems, as this had been previously linked with the shift of student activities from the physically and mentally beneficial ones to harmful ones (Oswald et al., 2020). The participants were students and so, their developing physiological systems were sensitive. Excessive class loads might harm their neurological development like in the region of the hypothalamic-pituitary-adrenal (HPA) axis (Brunetti et al., 2016; Wahlstrom et al., 2010). The authors attempted to analyse statistically which of those physiological challenges were more associated with the weekly class load. It is shown in Table III. The propensity of the challenges that the participants underwent was found to be increased with the increase of the weekly class load. For some of those challenges, this relationship was found to be almost linear (with correlation co-efficients close to one).

The weekly class load of the majority of the students was clearly higher than the screen time people are recommended to allocate (Chang et al., 2018; Tremblay et al., 2016, 2017). Moreover, this online class screen time was not the students' only screen time but was in addition to the students' already existing television, computer or
Table III: Association of the physiological challenges with the weekly class load

\begin{tabular}{|c|c|c|c|c|c|}
\hline $\begin{array}{l}\text { Physiological } \\
\text { challenges }\end{array}$ & $\begin{array}{l}\text { Chi } \\
\text { square } \\
\text { test } \\
\text { statistic }\end{array}$ & $\begin{array}{l}\text { Corresponding } \\
\text { chi square } \\
\text { critical value }\end{array}$ & $\begin{array}{l}\text { Association } \\
\text { status }\end{array}$ & $p$ value & $\begin{array}{l}\text { Significance } \\
\text { of the } \\
\text { finding* }\end{array}$ \\
\hline Headache & 44.8935 & 9.488 & $\begin{array}{l}\text { Association } \\
\text { present }\end{array}$ & $<0.00001$ & Significant \\
\hline Eye problems & 42.3582 & 9.488 & $\begin{array}{l}\text { Association } \\
\text { present }\end{array}$ & $<0.00001$ & Significant \\
\hline Fatigue & 16.4912 & 9.488 & $\begin{array}{l}\text { Association } \\
\text { present }\end{array}$ & 0.002426 & Significant \\
\hline $\begin{array}{l}\text { Hearing } \\
\text { problems }\end{array}$ & 18.9128 & 9.488 & $\begin{array}{l}\text { Association } \\
\text { present }\end{array}$ & 0.000818 & Significant \\
\hline Dizziness & 16.3712 & 9.488 & $\begin{array}{l}\text { Association } \\
\text { present }\end{array}$ & 0.002559 & Significant \\
\hline Frustration & 23.7220 & 9.488 & $\begin{array}{l}\text { Association } \\
\text { present }\end{array}$ & 0.000091 & Significant \\
\hline $\begin{array}{l}\text { Internet } \\
\text { addiction }\end{array}$ & 15.8342 & 9.488 & $\begin{array}{l}\text { Association } \\
\text { present }\end{array}$ & 0.003250 & Significant \\
\hline $\begin{array}{l}\text { Sleeping } \\
\text { problems }\end{array}$ & 33.2566 & 9.488 & $\begin{array}{l}\text { Association } \\
\text { present }\end{array}$ & $<0.00001$ & Significant \\
\hline $\begin{array}{l}\text { Backpain/ } \\
\text { neckpain }\end{array}$ & 15.7685 & 9.488 & $\begin{array}{l}\text { Association } \\
\text { present }\end{array}$ & 0.003346 & Significant \\
\hline $\begin{array}{l}\text { Increased } \\
\text { anger }\end{array}$ & 19.7326 & 9.488 & $\begin{array}{l}\text { Association } \\
\text { present }\end{array}$ & 0.000564 & Significant \\
\hline $\begin{array}{l}\text { High blood } \\
\text { pressure }\end{array}$ & 32.3535 & 9.488 & $\begin{array}{l}\text { Association } \\
\text { present }\end{array}$ & $<0.00001$ & Significant \\
\hline
\end{tabular}



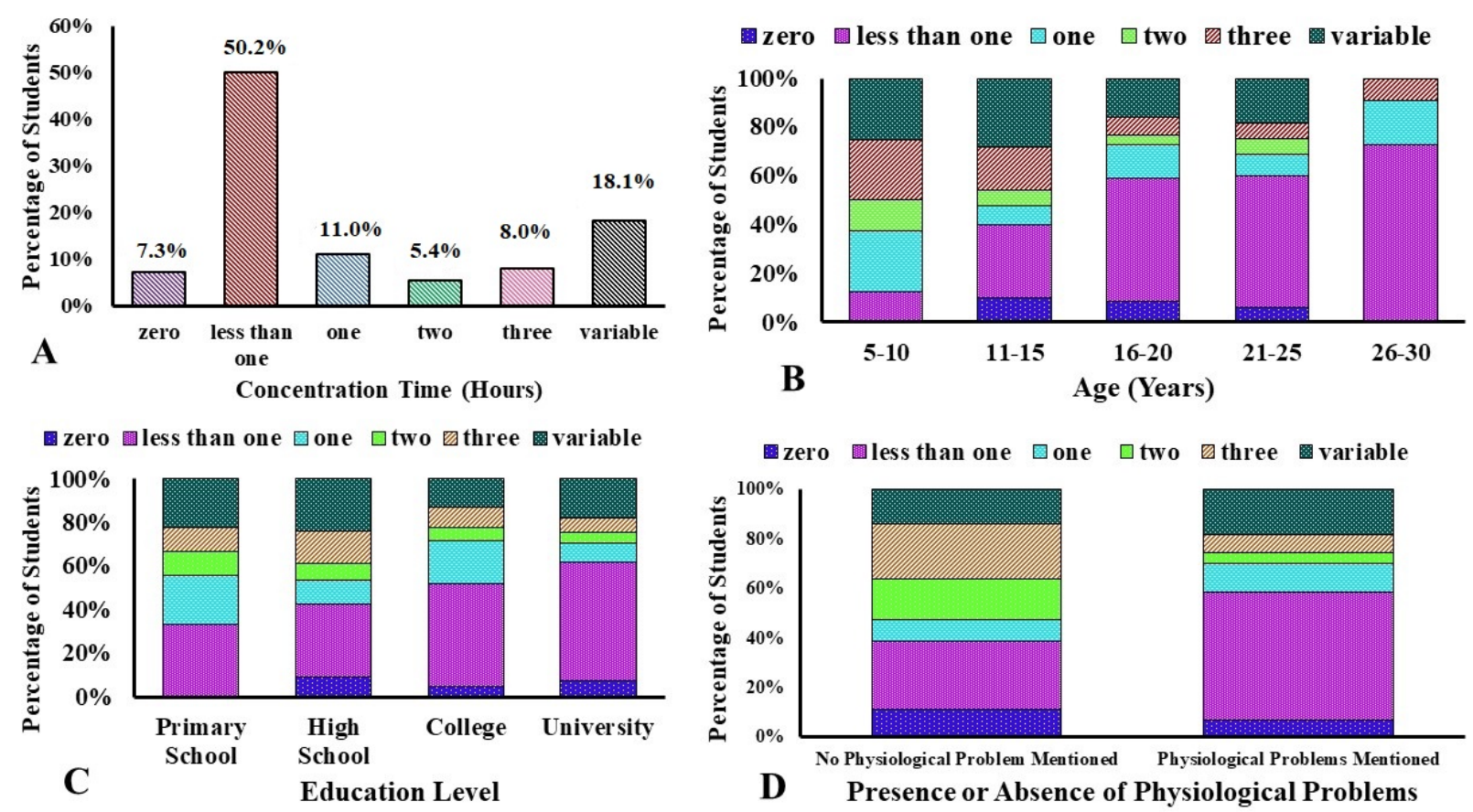

Figure 4: A. Concentration time pattern among the participants; B. Age-based concentration time breakdown; C. Education level-based concentration time breakdown; D. Association between the concentration time and the mentioned physiological challenges.

video games' screen time. This will have add to the strain on the physiological processes of the students unless they cut back their previous screen time, this might have contributed to the problems mentioned.

\section{Concentration Time}

Participants were asked for how much time they could concentrate in a single class. The results are displayed in Figure $4 \mathrm{~A} .57 .5 \%$ of the participants stated that they could not concentrate for 1 hour or more. Different class lengths were described by participants of different demographics and the lengths ranged from 30 minutes to more than three hours. It is incontrovertible that classes should be designed in a way that helps students concentrate, and classes which are too long obstruct that concentration. Besides, if students cannot focus in the class, the very purpose of the class is lost. A shorter class length was reported to have a positive effect on the students' performance but the authors opined that it was dependent on the students (Ewer et al., 2002). The attention span of the students was reported to get briefer with the progress of the class which meant students could focus for a higher period of time in the beginning of the class than in the end. Additionally, shorter class sessions and appropriate breaks might produce better student understanding altogether. It should be specified that it was not suggested total class time be reduced, rather shorter classes should be taken in a more frequent manner (Trout, 2018). On a different note, $18.1 \%$ of the participants said that their concentration time was variable and it depended on the class; they could concentrate for an extended period of time if the teacher was conducting the class in an appealing way. Several studies suggested that the attention of the students varied mostly because of the teachers and not because of the class format (Bradbury, 2016). Therefore, class lengths should be designated according to the students' capability and classes should be conducted in an interesting manner.

It was seen that the average concentration time decreased with the increase in age and education level in a statistically significant manner ( $p$ values of 0.0236 and 0.0257 , respectively). It was previously reported that older students were less engaging in classes than the younger ones (Martin, 2009). It was also found that students who were not suffering from physiological challenges or problems from online classes reported increased concentration time than those who were suffering ( $p=$ 0.0002). These findings have been illustrated in Figure $4 \mathrm{~B}$, C, D. The authors aimed to identify which physiological 
problem was associated with decreased concentration time and the answer was insomnia or sleeping problems ( $p=0.0303$ ). Young adults were reported to foster the habit of delayed sleeping which resulted in decreased sleep-time and sleep problems and ultimately affected their concentration ability (Heijden et al., 2018). Similar events might have been responsible in this case.

\section{Use of Medications}

Among the participants who were facing at least one physiological challenge from attending online classes, only $7.4 \%$ consulted a physician but $36.8 \%$ were taking medications. This resulted in a self-medication rate of $82.4 \%$. High blood pressure, eye problems and ear problems were the physiological problems for which a relatively higher percentage of participants consulted a physician whereas fatigue and headaches were some of the most ignored problems. The commonly described medications included pain medications, sleep medications and eye medications. This is a serious issue because selfmedicating on drugs, even over the counter drugs, can be detrimental to the health of the individual because of possible interactions with other drugs or foods (Amoako et al., 2003). This is a health issue which plagues the world (Sarahroodi et al., 2012), and in this study the spreading of health-system misuse among Bangladeshi students was evident. Lack of available healthcare services, cost and easy access to drugs were reported to be responsible for this (Alkhawaldeh et al., 2020). The pandemic might have been a deterrent to consult a physician too.

\section{Other Patterns and Findings}

It was found that female participants were more likely to face these physiological challenges $(p=0.003)$, so were older $(p=0.041)$ and university level students $(p=0.001)$. The prevalence of backpain/neck pain from attending online classes was found to be higher in female participants than male ones $(p=0.024)$. Research about sex-gap in impacts of COVID-19 is scarce, but from the little that has been done, it is clear that women have been more affected by this pandemic. This group has also been reported as disproportionately disadvantaged with regard to health services (Wenham et al., 2020).

$62.5 \%$ and $26.1 \%$ of the participants used headphones and loudspeakers, respectively, while attending online classes whereas $11.4 \%$ used both. The use of headphones was found to be associated with ear problems in a statistically significant manner $(p=0.0003)$. The long-term use of this device was reported to cause hearing impairment and other adverse effects on the ear (Widén et al., 2017). The use of loudspeakers could be an alternative, but might not be feasible for all students as they attended classes in different environments. An appropriate break between classes might give them an opportunity to dislodge the headphones and give the ears a rest.

The most used online platforms for online classes included Zoom, Google Meet, Facebook and Youtube. Participants were found to use smartphones, laptops, personal computers (PCs) and tablet computers (tabs) for using these platforms and attending classes. Smartphones were found to be more likely to cause eye problems than other devices and tabs were found to be the safest in this regard; This finding was statistically significant ( $p=0.018$ ). However, tabs might not be affordable for all students and smartphones were already ubiquitous even among lowand middle-income families (Clark, 2020). Therefore, avoiding smartphones might not be a financially practical solution. Reducing other screen time and smartphone use for other purposes might be beneficial in this regard.

\section{Conclusion}

The transition from traditional to online education was not easy for neither students nor teachers. The students had been trying to adapt to the new normal and in doing so, had been facing several physiological challenges which might have long-term adverse effects on their health if not addressed quickly and appropriately. Stopping online classes altogether may not be a feasible idea. Virtual classes are the only viable option that allows students to continue institutional learning activities nationally during this pandemic. However, it is anticipated that implementing some of the recommendations given by participants in this study, may lessen students' grievances and help them adjust to the new online education paradigm. The study had limitations regarding the sample size and the sampling distribution. Further extensive studies involving larger and more representative sample size are required to get more conclusive information.

\section{Acknowledgement}

The authors would like to extend their gratitude towards Samiha Sayeed and the members of Dhaka University Pharma Club (DUPC) for assisting in completing this study. 


\section{Funding information}

This research did not receive any specific grant from funding agencies in the public, commercial, or not-forprofit sectors.

\section{Competing interests}

None

\section{References}

Al-Amin, M., Al Zubayer, A., Deb, B., \& Hasan, M. (2021). Status of tertiary level online class in Bangladesh: students' response on preparedness, participation and classroom activities. Heliyon, 7(1), e05943. https://doi.org/10.1016/j.heliyon.2021.e05943

Alkhawaldeh, A., Al Omari, O., ALBashtawy, M., Khraisat, O., Al Dammerry, K., Gharaibeh, S.F., \& Ayasrah, I. (2020). Assessment of selfmedication use among university students. International Journal of Nursing, 7, 1-7. https://doi.org/10.15640/ijn.v7n1a1

Amoako, E.P., Richardson-Campbell, L., \& Kennedy-Malone, L. (2003). Self-Medication with over-the-counter Drugs Among Elderly Adults. Journal of Gerontological Nursing, 29(8), 10-15. https://doi.org/ 10.3928/0098-9134-20030801-05

Bao, W. (2020). COVID-19 and online teaching in higher education: A case study of Peking University. Human Behavior and Emerging Technologies, 2(2), 113-115. https://doi.org/10.1002/hbe2.191

Barbour, M., Brown, R., Waters, L.H., Hoey, R., Hunt, J.L., Kennedy, K., Ounsworth, C., Powell, A., \& Trimm, T. (2011). Online and Blended Learning: A Survey of Policy and Practice from K-12 Schools around the World. International Association for K-12 Online Learning.

Basdav, J., Haffejee, F., \& Puckree, T. (2016). Impact of headaches on university students in Durban, South Africa. SpringerPlus, 5(1), 1679. https://doi.org/10.1186/s40064-016-3372-1

Bradbury, N.A. (2016). Attention span during lectures: 8 seconds, 10 minutes, or more? Advances in Physiology Education, 40(4), 509-513. https://doi.org/10.1152/advan.00109.2016

Brunetti, V. C., O'Loughlin, E. K., O'Loughlin, J., Constantin, E., \& Pigeon, É. (2016). Screen and nonscreen sedentary behavior and sleep in adolescents. Sleep Health, 2(4), 335-340.

Cairns, D. (2011). Youth, precarity and the future: Undergraduate housing transitions in Portugal during the economic crisis. Sociologia, Problemas e Práticas, 66, 9-25.

Chang, F.-C., Chiu, C.-H., Chen, P.-H., Miao, N.-F., Chiang, J.-T., \& Chuang, H.-Y. (2018). Computer/mobile device screen time of children and their eye care behavior: The roles of risk perception and parenting. Cyberpsychology, Behavior, and Social Networking, 21(3), 179-186.

Chaput, J.-P., Colley, R. C., Aubert, S., Carson, V., Janssen, I., Roberts, K. C., \& Tremblay, M. S. (2017). Proportion of preschool-aged children meeting the Canadian 24-Hour Movement Guidelines and associations with adiposity: Results from the Canadian Health Measures Survey. BMC Public Health, 17(5), 147-154
Chen, T., Peng, L., Yin, X., Rong, J., Yang, J., \& Cong, G. (2020). Analysis of user satisfaction with online education platforms in China during the COVID-19 pandemic. Healthcare, 8(3), 200.

Cillero, I.H., \& Jago, R. (2010). Systematic review of correlates of screenviewing among young children. Preventive Medicine, 51(1), 3-10.

Clark, J.T. (2020). Chapter 62-Distance education. In E. ladanza (Ed.), Clinical Engineering Handbook (Second Edition) (pp. 410-415). Academic Press. https://doi.org/10.1016/B978-0-12-813467-2.00063-8

Deleu, D., Khan, M.A., Humaidan, H., Al Mantheri, Z., \& Al Hashami, S. (2001). Prevalence and clinical characteristics of headache in medical students in Oman. Headache: The Journal of Head and Face Pain, 41(8), 798-804.

Delgado-Floody, P., Carter-Thuillier, B., Guzmán-Guzmán, I.P., LatorrreRomán, P., \& Caamaño-Navarrete, F. (2020). Low indicators of personal and social development in Chilean schools are associated with unimproved academic performance: A national study. International Journal of Educational Research, 104. https://doi.org/10.1016/ j.ijer.2020.101651

Demuyakor, J. (2020). Coronavirus (COVID-19) and online learning in higher institutions of education: A survey of the perceptions of Ghanaian international students in China. Online Journal of Communication and Media Technologies, 10(3).

Duch, H., Fisher, E.M., Ensari, I., \& Harrington, A. (2013). Screen time use in children under 3 years old: A systematic review of correlates. International Journal of Behavioral Nutrition and Physical Activity, 10(1), 102.

Ewer, S., Greer, O., Bridges, W., \& Lewis, B. (2002). Class length and student performance: An extended study. International Advances in Economic Research, 8(2), 160-168. https://doi.org/10.1007/BF02295347

Fedynich, L. V. (2013). Teaching beyond the classroom walls: The pros and cons of cyber learning. Journal of Instructional Pedagogies, 13.

Ferrari, G. L. de M., Pires, C., Solé, D., Matsudo, V., Katzmarzyk, P. T., \& Fisberg, M. (2019). Factors associated with objectively measured total sedentary time and screen time in children aged 9-11 years. Jornal de Pediatria, 95(1), 94-105.

Gillett-Swan, J. (2017). The challenges of online learning: Supporting and engaging the isolated learner. Journal of Learning Design, 10(1), 20-30.

Górnicka, M., Drywień, M.E., Zielinska, M.A., \& Hamulka, J. (2020). Dietary and lifestyle changes during COVID-19 and the subsequent lockdowns among Polish adults: A Cross-sectional online survey PLifeCOVID-19 study. Nutrients, 12(8), 2324.

Hafezi, S., Zare, H., Mehri, S.N., \& Mahmoodi, H. (2010). The Multidimensional Fatigue Inventory validation and fatigue assessment in Iranian distance education students. 2010 4th International Conference on Distance Learning and Education, 195-198.

Heijden, K.B. van der, Vermeulen, M.C.M., Donjacour, C.E.H.M., Gordijn, M.C.M., Hamburger, H.L., Meijer, A.M., Rijn, K.J. van, Vlak, M., \& Weysen, T. (2018). Chronic sleep reduction is associated with academic achievement and study concentration in higher education students. Journal of Sleep Research, 27(2), 165-174. https://doi.org/10.1111/ jsr.12596

Islam, A., \& Islam, N. (2008). Effectiveness of Different Medium of Education to Imparting Knowledge at Bangladesh Open University. Online Submission, 9(1), 44-53.

Islam, M.S., Sujan, M.S.H., Tasnim, R., Ferdous, M.Z., Masud, J.H.B., Kundu, S., Mosaddek, A.S.M., Choudhuri, M.S.K., Kircaburun, K., \& Griffiths, M.D. (2020). Problematic internet use among young and adult population in Bangladesh: Correlates with lifestyle and online activities 
during the COVID-19 pandemic. Addictive Behaviors Reports, 12, 100311. https://doi.org/10.1016/j.abrep.2020.100311

Kenny, A. (2002). Online learning: Enhancing nurse education? Journal of Advanced Nursing, 38(2), 127-135.

Khati, K., \& Bhatta, K. (2020). Challenges of Online Education during COVID-19 Pandemic in Nepal. International Journal of Entrepreneurship and Economic Issues, 4(1), 45-49.

Kim, M.G., Hong, S.M., Shim, H.J., Kim, Y.D., Cha, C.I., \& Yeo, S.G. (2009). Hearing threshold of Korean adolescents associated with the use of personal music players. Yonsei Medical Journal, 50(6), 771-776.

Kumar, A., Mathew, K., Alexander, S.A., \& Kiran, C. (2009). Output sound pressure levels of personal music systems and their effect on hearing. Noise and Health, 11(44), 132.

Levine, L.E., \& Waite, B.M. (2000). Television viewing and attentional abilities in fourth and fifth grade children. Journal of Applied Developmental Psychology, 21(6), 667-679.

Lissak, G. (2018). Adverse physiological and psychological effects of screen time on children and adolescents: Literature review and case study. Environmental Research, 164, 149-157. https://doi.org/10.1016/ j.envres.2018.01.015

Martin, A. J. (2009). Motivation and engagement across the academic life span: A developmental construct validity study of elementary school, high school, and university/college students. Educational and Psychological Measurement, 69(5), 794-824.

Menon, B., \& Kinnera, N. (2013). Prevalence and characteristics of migraine in medical students and its impact on their daily activities. Annals of Indian Academy of Neurology, 16(2), 221. https://doi.org/ 10.4103/0972-2327.112472

Mishra, L., Gupta, T., \& Shree, A. (2020). Online teaching-learning in higher education during lockdown period of COVID-19 pandemic. International Journal of Educational Research Open. https://doi.org/ 10.1016/j.jjedro.2020.100012

Montagni, I., Guichard, E., Carpenet, C., Tzourio, C., \& Kurth, T. (2016). Screen time exposure and reporting of headaches in young adults: $\mathrm{A}$ cross-sectional study. Cephalalgia, 36(11), 1020-1027.

Nikkelen, S.W., Valkenburg, P. M., Huizinga, M., \& Bushman, B.J. (2014). Media use and ADHD-related behaviors in children and adolescents: $A$ meta-analysis. Developmental Psychology, 50(9), 2228.

Oswald, T.K., Rumbold, A.R., Kedzior, S.G., \& Moore, V.M. (2020). Psychological impacts of "screen time" and "green time" for children and adolescents: A systematic scoping review. PloS One, 15(9).

Özmert, E., Toyran, M., \& Yurdakök, K. (2002). Behavioral correlates of television viewing in primary school children evaluated by the child behavior checklist. Archives of Pediatrics \& Adolescent Medicine, 156(9), 910-914.

Page, A.S., Cooper, A.R., Griew, P., \& Jago, R. (2010). Children's screen viewing is related to psychological difficulties irrespective of physical activity. Pediatrics, 126(5).

Peng, J.-H., Tao, Z.-Z., \& Huang, Z.-W. (2007). Risk of damage to hearing from personal listening devices in young adults. Journal of Otolaryngology, 36(3), 181-185.

Picciano, A.G. (2017). Theories and frameworks for online education: Seeking an integrated model. Online Learning, 21(3), 166-190.

Poitras, V.J., Gray, C.E., Janssen, X., Aubert, S., Carson, V., Faulkner, G., Goldfield, G.S., Reilly, J.J., Sampson, M., \& Tremblay, M.S. (2017). Systematic review of the relationships between sedentary behaviour and health indicators in the early years (0-4 years). BMC Public Health, 17(5), 868.

Robinson, C.C., \& Hullinger, H. (2008). New benchmarks in higher education: Student engagement in online learning. Journal of Education for Business, 84(2), 101-109.

Roth, J.J., Pierce, M., \& Brewer, S. (2020). Performance and Satisfaction of Resident and Distance Students in Videoconference Courses. Journal of Criminal Justice Education, 31(2), 1-15. https://doi.org/ 10.1080/10511253.2020.1726423

Sarahroodi, S., Maleki-Jamshid, A., Sawalha, A. F., Mikaili, P., \& Safaeian, L. (2012). Pattern of self-medication with analgesics among Iranian University students in central Iran. Journal of Family \& Community Medicine, 19(2), 125.

Stack, S. (2015). Learning Outcomes in an online vs traditional course. International Journal for the Scholarship of Teaching and Learning, 9(1), $1-20$.

Tamana, S.K., Ezeugwu, V., Chikuma, J., Lefebvre, D.L., Azad, M.B., Moraes, T.J., Subbarao, P., Becker, A.B., Turvey, S.E., \& Sears, M.R. (2019). Screen-time is associated with inattention problems in preschoolers: Results from the CHILD birth cohort study. PloS One, 14(4).

The Lancet Child \& Adolescent Health. (2018). Growing up in a digital world: Benefits and risks. The Lancet. Child \& Adolescent Health, 2(2), 79. https://doi.org/10.1016/S2352-4642(18)30002-6

Tremblay, M.S., Carson, V., Chaput, J.-P., Connor Gorber, S., Dinh, T., Duggan, M., Faulkner, G., Gray, C. E., Gruber, R., Janson, K., Janssen, I., Katzmarzyk, P.T., Kho, M.E., Latimer-Cheung, A.E., LeBlanc, C., Okely, A.D., Olds, T., Pate, R.R., Philips, A., Poitras, V.J., Rodenburg, S., Sampson, M., Saunders, T.J., Stone, J.A., Stratton, G., Weiss, S.K., \& Zehr, L. (2016). Canadian 24-hour movement guidelines for children and youth: An integration of physical activity, sedentary behaviour, and sleep. Applied Physiology, Nutrition, and Metabolism, 41(6). https://doi.org/10.1139/ apnm-2016-0151

Tremblay, M. S., Chaput, J.-P., Adamo, K. B., Aubert, S., Barnes, J. D., Choquette, L., Duggan, M., Faulkner, G., Goldfield, G. S., \& Gray, C. E. (2017). Canadian 24-hour movement guidelines for the early years (0-4 years): An integration of physical activity, sedentary behaviour, and sleep. BMC Public Health, 17(5), 874.

Trout, B. (2018). The effect of class session length on student performance, homework, and instructor evaluations in an introductory accounting course. Journal of Education for Business, 93(1), 16-22.

Unger, S., \& Meiran, W. (2020). Student attitudes towards online education during the COVID-19 viral outbreak of 2020: Distance learning in a time of social distance. International Journal of Technology in Education and Science, 4(4), 256-266.

Viner, R.M., Russell, S.J., Croker, H., Packer, J., Ward, J., Stansfield, C., Mytton, O., Bonell, C., \& Booy, R. (2020). School closure and management practices during coronavirus outbreaks including COVID-19: A rapid systematic review. The Lancet Child \& Adolescent Health. 4(5), 397-404.

Wahlstrom, D., Collins, P., White, T., \& Luciana, M. (2010). Developmental changes in dopamine neurotransmission in adolescence: Behavioral implications and issues in assessment. Brain and Cognition, 72(1), 146159.

Wenham, C., Smith, J., Davies, S.E., Feng, H., Grépin, K.A., Harman, S., Herten-Crabb, A., \& Morgan, R. (2020). Women are most affected by pandemics-Lessons from past outbreaks. Nature, 583(7815), 194-198. https://doi.org/10.1038/d41586-020-02006-z

Widén, S. E., Båsjö, S., Möller, C., \& Kähäri, K. (2017). Headphone Listening Habits and Hearing Thresholds in Swedish Adolescents. Noise \& Health, 19(88), 125-132. https://doi.org/10.4103/nah.NAH_65_16 